\title{
Translational implications of endothelial cell dysfunction in association with chronic allograft rejection
}

\author{
Sarah Bruneau ${ }^{1,2,3,4}$. Johannes Wedel ${ }^{1,2,3}$ • Fadi Fakhouri ${ }^{4}$ Hironao Nakayamaa ${ }^{1,5}$. \\ Leo Boneschansker ${ }^{1,2,3,6} \cdot$ Daniel Irimia $^{6} \cdot$ Kevin P. Daly ${ }^{1,2,3}$ - David M. Briscoe ${ }^{1,2,3}$
}

Received: 13 January 2015 / Revised: 3 March 2015 / Accepted: 12 March 2015 / Published online: 24 April 2015

(C) IPNA 2015

\begin{abstract}
Advances in therapeutics have dramatically improved short-term graft survival, but the incidence of chronic rejection has not changed in the past 20 years. New insights into mechanism are sorely needed at this time and it is hoped that the development of predictive biomarkers will pave the way for the emergence of preventative therapeutics. In this review, we discuss a paradigm suggesting that sequential changes within graft endothelial cells (EC) lead to an intragraft microenvironment that favors the development of chronic rejection. Key initial events include EC injury, activation and uncontrolled leukocyte-induced angiogenesis. We propose that all of these early changes in the microvasculature lead to abnormal blood flow patterns, local tissue hypoxia, and an associated overexpression of HIF-1 $\alpha$-inducible genes, including vascular endothelial growth factor. We also discuss how cell intrinsic regulators of mTOR-mediated signaling within EC are of critical importance in microvascular stability and may thus have a
\end{abstract}

David M. Briscoe

david.briscoe@childrens.harvard.edu

1 Transplant Research Program, Boston Children's Hospital, 300 Longwood Avenue, Boston, MA 02115, USA

2 Division of Nephrology, Department of Medicine, Boston Children's Hospital, 300 Longwood Avenue, Boston, MA 02115, USA

3 Department of Pediatrics, Harvard Medical School, Boston, MA, USA

4 INSERM UMR S-1064, Institut de Transplantation Urologie-Nephrologie (ITUN), Centre Hospitalier Universitaire (CHU) de Nantes, University of Nantes, Nantes, France

5 Vascular Biology Program, Department of Surgery, Boston Children's Hospital and Harvard Medical School, Boston, MA, USA

6 Department of Surgery, BioMEMS Resource Center, Massachusetts General Hospital, Harvard Medical School, Shriners Hospitals for Children, Boston, MA, USA role in the inhibition of chronic rejection. Finally, we discuss recent findings indicating that miRNAs may regulate EC stability, and we review their potential as novel non-invasive biomarkers of allograft rejection. Overall, this review provides insights into molecular events, genes, and signals that promote chronic rejection and their potential as biomarkers that serve to support the future development of interruption therapeutics.

Keywords Graft survival · Graft rejection · Biomarkers · Preventative therapeutics · Endothelial cells · Vascular endothelial growth factor $\cdot$ mTOR-mediated signaling . miRNA

\section{Introduction}

Renal transplantation is widely recognized as the treatment of choice for children with end-stage renal disease (ESRD) [1, 2]. The life expectancy benefit compared with chronic dialysis is significant [3], and graft survival can be superior to that in adult recipients [2]. However, the human immune response changes with increasing age, and some studies suggest that children are predisposed to an increased risk for both late acute rejection in addition to chronic rejection [4]. Indeed, recent analyses of the North American Pediatric Renal Trials and Collaborative Studies (NAPRTCS) registry data for 11, 603 pediatric renal transplants performed between 1987 and 2010 indicate that chronic rejection is the leading cause of graft failure, accounting for $\sim 40 \%$ of all index pediatric graft failures [4]. Current therapeutics are most efficient at targeting acute rejection, but have no effect on the progression of graft failure due to chronic rejection. Several groups [5-7], including our own group [8,9], have strongly advocated the development of mechanistic biomarkers to define the status of the alloimmune response at different times post-transplantation or to monitor indices of graft injury. This approach will support 
the prediction of chronic rejection such that new therapeutic interventions can be tested in clinical trials. However, the development and use of biomarkers demands an understanding of chronic rejection pathogenesis, which is likely driven by multiple factors, especially in a growing child.

In this review, we discuss a paradigm in which the evolution of sequential endothelial derived molecular events within the graft characterizes the progression of chronic rejection. We also review distinct cell intrinsic signals within endothelial cells (ECs) that function to sustain vascular stability and thus the intragraft microenvironment. The concepts described in this review open up avenues for translational research, including the development of biomarkers to predict disease initiation and possible therapeutic targets for intervention in the future.

\section{An endothelial cell-based paradigm to define chronic rejection pathogenesis}

The Banff classification [10-13] adopted terminology that defines chronic rejection based on pathology, but also takes into account active immune processes. In this manner, it is possible to define injury based on alloantibody-mediated rejection (AMR) and/or T-cell-mediated rejection (TCR). Chronic rejection can thus be classified as "chronic active antibody-mediated rejection", and/or "chronic active T-cellmediated rejection," and/or "interstitial fibrosis and tubular atrophy" (IFTA), based on whether the exact mechanism is understood $[12,13]$. The purpose of this review is to discuss a new paradigm that supports an understanding of pathogenesis and involves the effect of immunity on the local intragraft microenvironment. We focus our discussion on the identity of events, and molecules that drive EC-dependent responses to injury and the associated remodeling of the microvasculature. Since we do not discriminate between cellular or humoral immune responses, we will use the term "chronic rejection" to describe this process throughout the review.

Our proposed paradigm is based on the well-established observation that the graft microvascular EC represents a critical interface between the recipient immune response and the donor allograft. The unique anatomical location of the graft EC ensures that it is the primary target of alloimmunemediated injury $[14,15]$. To this end, it is not surprising that microvascular loss occurs as a consequence of all forms of rejection $[16,17]$. Furthermore, an increasing body of evidence indicates that the response of the microvasculature to injury is critical in both the initiation of, and the progression of chronic rejection. Microvascular ECs respond to cellmediated and humoral alloimmune responses by undergoing a characteristic process of activation. Several studies have shown that select mRNA and protein expression profiles within ECs [18-20], and/or select intracellular EC activation responses may serve as an indicator of immune targeting of the graft [8, 21-23]. Also, cytokines produced by mononuclear cell infiltrates induce the expression of MHC class I and II in addition to adhesion molecules and chemokines on EC that in turn result in the recruitment and activation of leukocytes within the graft. Growth factors produced by mononuclear cell infiltrates, including vascular endothelial growth factor (VEGF) [9, 24-27], elicit a "leukocyte-induced" angiogenesis response [28] that is a characteristic event in all cell-mediated immune responses [29]. Thus, dynamic changes occur within microvascular ECs in the initial course of an alloimmune inflammatory reaction.

We [22] and others [16, 30, 31] hypothesize that all these microvascular responses initiate the process of chronic rejection by creating abnormal microvascular networks and chaotic blood flow patterns within the local inflamed tissue [31-34] (Fig. 1). The associated shunting of blood causes local tissue hypoxia, which can result in tissue injury and microvascular

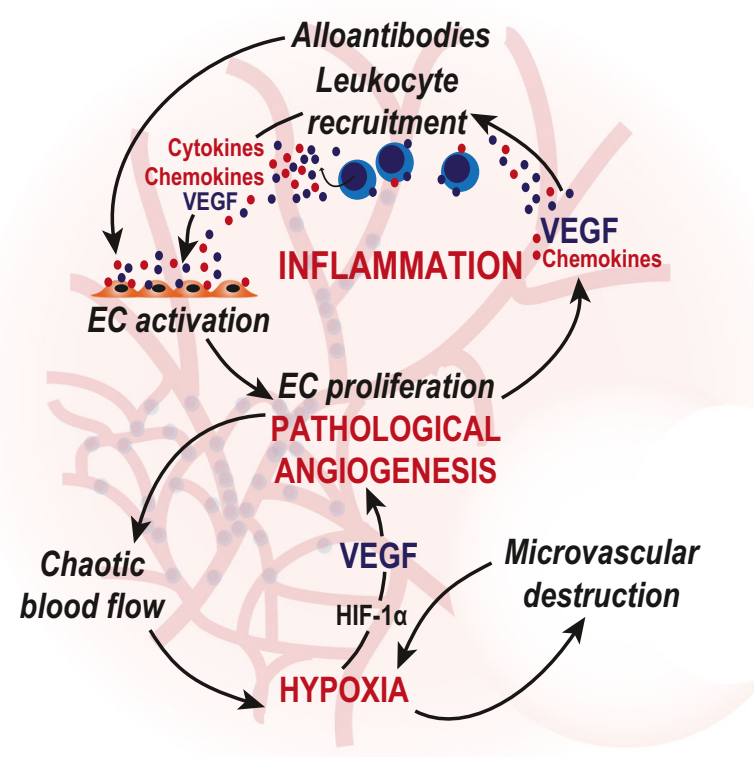

Fig. 1 Illustration shows how changes within the microvasculature may define the initiation and progression of chronic allograft rejection. Following organ transplantation, alloimmune targeting of microvascular endothelial cells (ECs) is the earliest event in the initiation of a proinflammatory intragraft microenvironment. Once targeted by cellular or humoral immunity, ECs become activated and express MHC class I and II molecules, adhesion molecules, and chemokines that promote ongoing recruitment and activation of leukocytes in the graft. These events also result in EC proliferation and the process of leukocyte-induced angiogenesis. Uncontrolled EC proliferation that occurs at early times in association with mononuclear cell infiltration leads to the formation of abnormal microvascular networks that in turn can result in chaotic blood flow patterns and local tissue hypoxia. Microvascular loss resulting from persistent injury to ECs amplifies tissue hypoxia, and all these events drive hypoxia-inducible factor (HIF)- $1 \alpha$-dependent activation of growth factors and chemokines. We propose that the overexpression of VEGF-A by infiltrating leukocytes and by the graft itself in response to hypoxia is central to this cycle of events within the microenvironment 
loss. Thus, similar to that described within tumors [35, 36], we have proposed that hypoxia-stimulated overexpression of growth and survival factors are key events in the initiation and progression of chronic rejection (Fig. 1) [22]. Indeed, Nicolls' group has demonstrated that local tissue hypoxia occurs within allografts at early times in association with leukocyte infiltration [33]. Further, they demonstrated that the induced expression of hypoxia-inducible factor (HIF-1 $\alpha$ ) is a physiological response to alloimmune inflammation, and that HIF- $1 \alpha$-inducible responses result in the expression of multiple growth factors [37], most notably VEGF. While these factors function to sustain microvascular integrity, at the same time they serve as leukocyte chemoattractants and as angiogenesis factors. We have thus proposed that the overexpression of VEGF and related growth factors are of central importance to the biology of an intragraft microenvironment that sustains chronic rejection.

Although beyond the scope of this review, several other events contribute to microvascular disease in association with chronic rejection. For instance, neutrophils participate in many aspects of the transplant rejection process, including ischemia-reperfusion injury, and acute and chronic rejection [38-40]. Importantly, following activation neutrophils release their DNA, histones, and neutrophil antimicrobial proteins, resulting in the formation of neutrophil extracellular traps (NETs) [41] that bind within microcapillaries and promote thrombosis [42] and/or the development of local vasculitis [43]. Elevated serum NET levels have been reported to be associated with organ injury, due in part to changes within the microcirculation $[44,45]$. NETs have also been shown to damage ECs and expose immunostimulatory molecules in association with systemic lupus, and similar mechanisms may be responsible for organ injury after transplantation [46]. Furthermore, it has been noted that reduced levels of NETs in the circulation following transplantation can be associated with improved graft function [47]. Thus, we speculate that the activation of neutrophils and NETosis within intragraft microcapillaries has the potential to augment hypoxia-induced changes in the microvasculature and disease that is associated with chronic rejection.

Another event that is worthy of note relates to the role of endothelial-to-mesenchymal transition (EndMT) in chronic rejection [48]. Data suggest that the presence of inflammatory cytokines in association with endothelial proliferation precedes EndMT, where ECs and/or pericytes dedifferentiate into collagen-secreting fibroblasts $[49,50]$ (and data not shown). In this manner, the pathological intragraft microenvironment, as illustrated in Fig. 1, that is associated with inflammation, local tissue hypoxia, and the overexpression of intragraft VEGF, may promote EndMT-dependent fibrosis and scarring. As will be discussed below, these collective findings suggest that the monitoring of molecular events associated with microvascular injury and repair, and/or intragraft expression of hypoxia-inducible growth factors may serve as predictive biomarkers of chronic rejection.

\section{Cell intrinsic regulation of microvascular stability within an allograft}

Understanding the regulation of key signals within the EC that are critical for microvascular stability may pave the way for the development of new interruption therapeutic strategies to target the initiation of the chronic rejection process. To this end, the mammalian target of the rapamycin (mTOR) signaling pathway has emerged as a critical mediator of EC stability [51-55]. Furthermore, the regulation of signals mediated through this pathway is likely of great importance in both the initiation and the progression of chronic rejection [56-58]. Cytokines produced by leukocytic infiltrates within the graft, and the binding of donor-specific antibodies (DSA) to the microvasculature, induce mTOR-dependent intracellular signals $[59,60]$ (illustrated in Fig. 2). Responses include the characteristic expression of adhesion molecules and chemokines [53-55], and an activated EC phenotype that promotes mononuclear cell recruitment [21, 55, 58-61]. mTOR/ Akt-induced responses may also disrupt the allograft microenvironment through their potent effects to elicit EC proliferation and angiogenesis [22, 51]. Thus, while a physiological response to injury and inflammation, excessive mTOR activity within EC drives many molecular processes within the microenvironment as key events in the biology of chronic rejection.

mTOR is a highly conserved serine/threonine kinase that constitutes the catalytic subunit of two structurally and functionally distinct protein complexes, called mTOR complex (mTORC)-1 and mTORC2 [62]. mTORC1 integrates signals from growth factors, energy status, oxygen, and amino acids to regulate a variety of metabolic processes involved in cell growth and proliferation $[62,63]$. mTORC1 is composed of mTOR, raptor (rapamycin-sensitive protein of TOR) [64], and mLST8 (mammalian lethal with SEC13 protein 8) [65]; it also associates with PRAS40 (proline-rich Akt substrate) [66] and DEPTOR (DEP domain-containing mTOR-interacting protein) [67], which function to negatively regulate the activity of the complex. Once activated, mTORC1 promotes protein synthesis by phosphorylating 4E-BP1 and S6K1, signals that enhance mRNA translation, ribosome synthesis, cell proliferation, and cellular growth [68]. mTORC1 has been found to be dysregulated in several diseases including cancer, diabetes, and obesity [63], and it is likely of great importance in chronic inflammatory disease states.

In contrast to mTORC1, little is known about upstream activation of mTORC2 or how it functions to facilitate downstream cellular function. mTORC2 activity classically results in the phosphorylation/activation of Akt (Ser473) and SGK1, 
Fig. 2 Illustration showing the central role of mammalian target of rapamycin (mTOR) signaling in ECs in the pathogenesis of chronic allograft rejection. Upon binding to graft microvascular endothelial cells (ECs), leukocytes, inflammatory cytokines, growth factors [including vascular endothelial growth factor (VEGF); Fig. 1] and alloantibodies activate PI3K/Akt/mTOR-mediated signals. Assembly of the mTORC2 complex results in the phosphorylation and activation of Akt kinase, which in turn activates $\mathrm{mTORC} 1$ and its substrates 4EBP1 and S6K1. Collectively, these signals result in EC activation, migration and proliferation. In addition, Aktmediated signals enhance the activity of ERK1/2, which also promotes EC activation. The endogenous protein DEPTOR inhibits mTORC1, ERK1/2 and STAT-1 signaling in ECs, highlighting its major function as a cell-intrinsic regulator of EC activation responses. Several miRNAs also control the activity of the mTOR pathway, and EC activation. Notably, endothelialspecific miR-126 functions to inactivate both PI3K/Akt- and ERK1/2-mediated signals and thus maintain EC quiescence

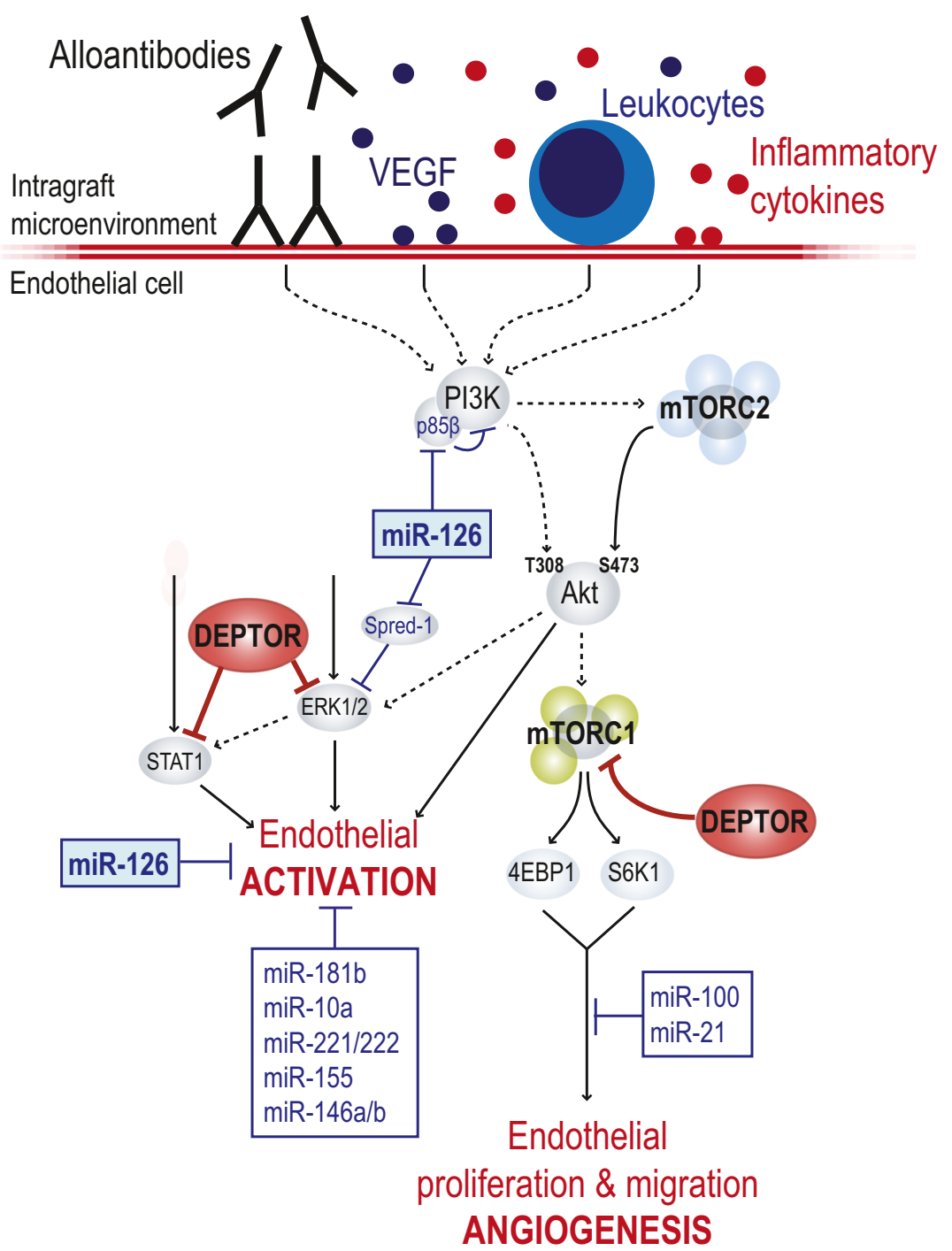

well established to function in cell survival [69]; it also functions in actin and cytoskeletal organization [70, 71]. The mTORC2 complex is composed of mTOR, rictor (rapamycin-insensitive companion of mTOR) [70], mSIN1 (mammalian stress-activated protein kinase interacting protein) [72], Protor (protein observed with rictor)-1 [73] and mLST8 [71], and associates with the endogenous negative regulator DEPTOR [67]. There is crosstalk between both mTOR complexes in as much as mTORC1/S6K1-mediated activity may result in the phosphorylation of rictor, to inhibit mTORC2 complex formation [74]. In this manner, mTOR activity is maintained at a strict "level" and it may be oscillatory in nature $[63,75]$ such that survival, cell growth, and proliferation are maintained.

However, it is important to note that the mTOR pathway interacts with many other signaling cascades and promotes significant crosstalk among intracellular signals. Thus, the cell-intrinsic regulation of mTOR is potentially important in the deregulation of other signaling networks involved in EC biological responses (Fig. 2). For instance, we have recently reported that the adaptor protein DEPTOR, an intrinsic inhibitor of mTOR signaling [67], is also potent for regulating MAPK- and STAT-induced signaling in ECs [58]. Interestingly, the treatment of ECs with TNF $\alpha$ markedly reduces intracellular levels of DEPTOR (within minutes to hours) presumably by changing its structure such that it is targeted for ubiquitination [76, 77]. Consistent with its cell-intrinsic regulatory effects, we also find that reduced levels of intracellular DEPTOR (via siRNA knockdown) are associated with marked EC activation, characterized by a massive release of $\mathrm{T}$ cell chemoattractant chemokines and the induction of cell surface adhesion molecules (e.g., VCAM-1, ICAM-1) analogous to activation in response to cytokines. Reduced levels of cell-intrinsic DEPTOR promotes leukocyte-EC adhesion and enhanced angiogenesis in vitro, which is attenuated by the combined inhibition of mTOR and ERK activity. Our findings 
support the possibility that sustained DEPTOR expression stabilizes the microvasculature and thus may have a notable effect on the inhibition of EC activation and pathological angiogenesis. To this end, in pilot experiments we have found that overexpression of DEPTOR in ECs is efficient at preventing TNF $\alpha$-induced expression of adhesion molecules in vitro; and, using a transgenic mouse, we have found that forced overexpression of DEPTOR within cardiac transplants prolongs graft survival in vivo in an established fully MHCmismatched mouse model (unpublished data). One could therefore hypothesize that novel small molecule inhibitors of DEPTOR degradation [78], or agents that increase DEPTOR activity [79], will be anti-inflammatory and prevent the initiation of chronic rejection. Interestingly, recent studies have shown that DEPTOR is also functional in non-ECs, including proximal tubular epithelial cells [80], further supporting the concept that sustaining levels of its expression may be therapeutic to maintain intragraft homeostasis.

\section{miRNA-mediated regulation of $\mathrm{EC}$ responses and their potential role in chronic allograft rejection}

It is increasingly apparent that miRNAs function to regulate EC activation, and that they are well established to play a critical role in the control of microvascular stability. Furthermore, an increasing number of studies indicate that miRNAs are functional in the maintenance of microvascular stability post-transplant $[81,82]$. miRNAs have been shown to be secreted in biological fluids within microparticles, where their expression is extremely stable [83, 84], and accumulating data indicate their tremendous potential as non-invasive biomarkers of chronic vascular diseases, including allograft rejection ([81, 85-87] and discussed below).

Micro-RNAs (miRNAs) are small (20-22 nucleotides) endogenous non-coding RNAs that regulate gene expression through their binding to target mRNAs and the inhibition of target mRNA translation. miR-126 is the only EC-specific miRNA described to date [88, 89], where it functions to sustain vascular homeostasis in response to injury. In mouse models $[89,90]$, the deletion of miR-126 is associated with defects in EC proliferation, migration, and angiogenesis; in zebrafish, knockdown of miR-126 results in a loss of vascular integrity during embryonic development [88]. miR-126 augments VEGF-inducible responses within ECs by directly repressing negative regulators of $\mathrm{PI}-3 \mathrm{~K} / \mathrm{Akt} / \mathrm{mTOR}$ signaling. Consistent with these findings, miR-126 silencing in mice using a single dose of antagomir-126 was found to impair ischemia-induced angiogenic responses [91]. miR-126 has also been reported to function in the regulation of EC activation and in leukocyte-EC interactions in part by inhibiting the inducible expression of VCAM-1 [92, 93]. In general, these observations suggest that miR-126-regulated responses might be of great biological importance in EC-dependent events associated with chronic rejection, and its potential as a biomarker is currently being studied.

In EC, miR-100 has been reported to regulate mTOR activity and attenuate signaling responses, including cell proliferation [94]. In accordance with these findings, inhibition of miR-100 in vivo using specific antagomirs results in increased angiogenesis [94]. miR-21 was also recently reported to mediate rapamycin-induced suppression of EC proliferation and migration [95]. Treatment of ECs with rapamycin significantly increased the expression of miR-21, and blockade of miR21 (using specific inhibitors) reduced the effects of rapamycin on EC growth and mobility [95]. In addition, miR-21 has been found to play a major role in vascular remodeling in an ECspecific miR-21 knockout mouse model $[96,97]$.

Several additional miRNAs function as key regulators of EC proinflammatory responses and as mediators of inflammation resolution. Pober's group profiled the expression of miRNAs in TNF $\alpha$-activated EC and identified miR-31 and miR-17-3p as key regulators of E-selectin and ICAM-1 expression respectively [98]. Specific antagonism of these miRNAs increased neutrophil binding to cultured ECs, whereas transfection of ECs with their miRNA mimics decreased leukocyte-EC adhesion [98]. Several other miRNAs have also been found to inhibit EC activation responses, including miR181b [99], miR-10a [100], miR221/222, miR-155 [101], miR$146 \mathrm{a}$ and miR-146b [102], and there expression could therefore also constitute biomarkers of EC stability.

Collectively, these data indicate that miRNAs function in the cell-intrinsic regulation of EC responses associated with inflammation, and suggest that they might be of functional importance in the evolution of chronic rejection. miRNAs are secreted within microparticles as exosomes or shed microvesicles $[103,104]$ and can be detected in the blood and in biological fluids such as urine. Their expression is extremely stable as they are protected from RNase-mediated degradation within microparticles [83, 84]. Because of this unusual stability, the analysis of miRNAs has emerged as a promising non-invasive biomarker assay for a variety of human disease processes including transplant rejection [105].

\section{Biomarker strategies}

Diagnostic and prognostic assays to assess chronic rejection classically take the form of routine biopsy analyses of the graft in combination with organ-specific assessments of graft function. In addition, recent data suggest that it might be possible to use several classes of biomarkers to support the diagnosis of acute rejection and acute graft injury [106, 107]. Nevertheless, little emphasis has been placed on the use of molecular events and biomarkers that are associated with, and/or 
predict the development of chronic injury and chronic allograft rejection in ongoing clinical trials. To compound this issue, it is well known that current biopsystaining techniques, imaging tools, and assessments of organ function do not predict the future development of chronic rejection. Ideally, newly developed biomarkers will predict disease before it is established, and thus clinical trials will be able to promote interruption therapies according to the status of the intragraft microenvironment. Many studies have searched to identify such factors using high throughput screens of mRNAs, miRNAs, proteins, and cellular phenotypes in transplant biopsies, blood, and urine samples. Several promising markers have been identified, mostly through analyses of immunity-related molecules and genes. However, immune-specific biomarkers usually reflect ongoing inflammation/rejection and are suggested to be unlikely to predict the occurrence of chronic rejection months or years in the future.

The model that we have proposed is highly suggestive that intragraft expression and circulating levels of genes associated with vascular stability, injury, and repair within the allograft microenvironment will serve as predictive monitors of disease. Also, our model predicts that local hypoxia and the induced expression of HIF-1a-regulated genes such as VEGF-A and related growth factors will be characteristic of the initiation of the chronic rejection intragraft microenvironment. This model provides a strong rationale to screen for detectable EC injury and repair responses as central biomarkers of the initiation of chronic rejection. For instance, the overexpression of VEGF-A is predicted to serve as a prototype HIF-inducible gene and may serve as the earliest biomarker of a response to any form of immune-mediated injury to the microvascular ECs.

To test this possibility, we initially performed crosssectional analyses among circulating serum levels of angiogenic factors in cardiac transplant patients with/without established chronic rejection/disease [8]. Univariate analysis identified six proteins - angiopoietin-2, artemin, urinary plasminogen activator, and vasohibin, in addition to VEGF-A and VEGF-C - that were significantly associated with allograft vasculopathy, the sine qua non of chronic rejection. Further analysis identified three proteins-VEGF-A, VEGF-C, and platelet factor 4 (PF-4) - as the optimal biomarker set for the diagnosis of chronic rejection in this cohort. In a pilot study, we also tested whether these same factors predict chronic rejection [108]. Plasma levels were measured in a cohort of patients who were more than 2 years post-transplant, and all patients were followed for 5 years. At a median follow-up time of 4.7 years, we find that high circulating levels of VEGF-A identify a subgroup of recipients who subsequently develop adverse cardiac events over this time period. Thus, it is possible that low/basal plasma levels of VEGF-A identify a low-risk patient population, whereas high levels may identify a cohort that will benefit from an interruption therapy, before complications occur due to established disease. To further validate these observations, we are currently collaborating with the multicenter CTOT- 05 consortium to evaluate whether these angiogenesis-related factors predict the initiation of allograft vasculopathy/chronic rejection within the first posttransplant year [109].

It is also increasingly apparent that miRNAs constitute a new class of promising biomarkers for the prediction of allograft rejection. As discussed above, miRNAs are secreted into body fluids and their expression is extremely stable. Several groups have analyzed miRNA expression profiles in peripheral blood mononuclear cells [110, 111], serum [112], urine [113-115], and allograft biopsies [82] from transplanted patients, and have identified candidate miRNA biomarkers of rejection (reviewed in detail in Mas et al. [85]). Anglicheau et al. profiled the expression pattern of miRNAs in kidney graft biopsies and in peripheral blood and identified 7 miRNAs that were upregulated and 10 that were downregulated in biopsies of patients undergoing acute rejection [82]. Among those identified, miR-155 and miR-223 are established to function in the regulation of EC angiogenic and inflammatory responses [116-119], and to increase over the course of immunemediated EC injury in diabetic nephropathy, atherosclerosis [120, 121], and in association with EndMT [122]. Scian et al. correlated tissue miRNA signatures with profiles identified in paired urine samples [114]. They found that miR-142-3p, miR-204, and miR-211 were expressed in both tissue and urine in association with chronic kidney allograft rejection, suggesting that it might be possible to monitor miRNAs in urine as an effective diagnostic of chronic rejection. Maluf et al. also identified 22 urine miRNAs that were selective for chronic rejection [115], and performed a longitudinal analysis to define a subset that was expressed before histological evidence of allograft injury. Collectively, these findings suggest that changes in the expression of specific miRNAs within the urine might be reflective of an intragraft phenotype that is associated with chronic rejection. However, large-scale multicenter studies will be required to validate their potential to serve as predictive biomarkers.

\section{Summary}

An increasing body of data indicates that vascular injury and repair, and homeostatic angiogenic responses following organ 
transplantation occur in a dynamic manner. Clearly, events associated with the efficient repair of the microvascular endothelium after ischemia-reperfusion injury and alloimmunemediated damage will ensure long-term graft survival [17, 32]. However, sustained and uncontrolled microvascular injury and repair responses, including leukocyte-induced angiogenic responses, ultimately result in local tissue hypoxia and the induced expression of HIF-1 $\alpha$-regulated genes [31-34]. The paradigm described in this review identifies all these events as key features of the initiation of chronic rejection. In this manner, microvascular changes can induce growth factors and gene profiles that alter the intragraft microenvironment, and ongoing studies have validated the use of this paradigm for the development of early disease biomarkers.

\section{Key summary points}

1. Microvascular endothelial cells (ECs) respond to alloimmune targeting of the graft with sequential changes, including EC activation and leukocyte-induced angiogenesis.

2. These changes in the EC phenotype result in a proinflammatory intragraft microenvironment that favors the development of chronic rejection.

3. Regulators of mTOR-mediated signaling within ECs are of critical importance stability and the inhibition of chronic rejection.

4. miRNAs also constitute a major class of regulators of EC stability post-transplantation.

5. Monitoring intragraft EC molecular events that participate in the establishment of a proinflammatory microenvironment may provide biomarkers for the early detection of chronic rejection.

\footnotetext{
Acknowledgements The authors wish to acknowledge the support of Drs. Michael Klagsbrun, Debabrata Mukhopadhyay, Soumitro Pal, and David Sabatini for ongoing scientific collaborations.
}

Financial support and sponsorship The work cited in this review was supported by NIH Grants R01AI046756, R01AI92305, and R21AI114223 to DMB, by a Pfizer ARTS grant and by the Casey Lee Ball Foundation. LB was supported by NIH grants T32DK007726 and T32AI007529. SB was supported by an AST Fellowship grant and a grant from the Fondation pour la Recherche Médicale ARF20140129163. JW was supported by a fellowship grant from the German Research Foundation (DFG)

Conflicts of interest David M. Briscoe has received funding from the Roche Organ Transplantation Research Foundation, Astellas, Wyeth, Alexion, and Pfizer.

\section{Multiple choice questions (answers are provided following the reference list)}

1. The response of graft microvascular ECs to alloimmune targeting following transplantation includes:
a) The induced expression of adhesion molecules and chemokines
b) An uncontrolled angiogenesis response
c) A change in phenotype that promotes the recruitment of leukocytes within the graft
d) All of the above

2. Vascular endothelial growth factor (VEGF):
a) Is delivered within the graft by infiltrating mononu- clear cells
b) Is produced within the graft in response to local hypoxia
c) Acts as an angiogenesis factor
d) Acts as a leukocyte chemoattractant
e) All of the above

3. In ECs, mTOR signaling:
a) Is downregulated upon alloimmune targeting of the graft
b) Elicits cell proliferation, growth, and activation responses
c) Is induced by cell intrinsic expression of DEPTOR
d) All of the above

4. Micro-RNAs:

a) Function to promote the expression of target mRNAs

b) Can regulate EC activation and microvascular stability

c) Can be secreted in body fluids such as urine, where they are unstable and are rapidly degraded by RNases

d) All of the above

5. Among the following, which have been proposed as noninvasive biomarkers of chronic allograft rejection:
a) Plasma angiogenic factors
b) Plasma miRNAs
c) Urinary miRNAs
d) All of the above

\section{References}

1. Briscoe DM, Kim MS, Lillehei C, Eraklis AJ, Levey RH, Harmon WE (1992) Outcome of renal transplantation in children less than 2 years of age. Kidney Int 42:657-662 
2. Dharnidharka VR, Fiorina P, Harmon WE (2014) Kidney transplantation in children. N Engl J Med 371:549-558

3. UNOS (United Network for Organ Sharing National Data. 2011) http://www.unos.org/. Accessed 15 January 2011

4. Smith JM, Martz K, Blydt-Hansen TD (2013) Pediatric kidney transplant practice patterns and outcome benchmarks, 19872010: a report of the North American pediatric renal trials and collaborative studies. Pediatr Transplant 17:149-157

5. Li L, Khush K, Hsieh SC, Ying L, Luikart H, Sigdel T, Roedder S, Yang A, Valantine H, Sarwal MM (2013) Identification of common blood gene signatures for the diagnosis of renal and cardiac acute allograft rejection. PLoS One 8:e82153

6. Halloran PF, Pereira AB, Chang J, Matas A, Picton M, De Freitas D, Bromberg J, Serón D, Sellarés J, Einecke G, Reeve J (2013) Microarray diagnosis of antibody-mediated rejection in kidney transplant biopsies: an international prospective study (INTERCOM). Am J Transplant 13:2865-2874

7. Jackson JA, Kim EJ, Begley B, Cheeseman J, Harden T, Perez SD, Thomas S, Warshaw B, Kirk AD (2011) Urinary chemokines CXCL9 and CXCL10 are noninvasive markers of renal allograft rejection and BK viral infection. Am J Transplant 11:2228-2234

8. Daly KP, Seifert ME, Chandraker A, Zurakowski D, Nohria A, Givertz MM, Karumanchi SA, Briscoe DM (2013) VEGF-C, VEGF-A and related angiogenesis factors as biomarkers of allograft vasculopathy in cardiac transplant recipients. J Heart Lung Transplant 32:120-128

9. Reinders ME, Sho M, Izawa A, Wang P, Mukhopadhyay D, Koss KE, Geehan CS, Luster AD, Sayegh MH, Briscoe DM (2003) Proinflammatory functions of vascular endothelial growth factor in alloimmunity. J Clin Invest 112:1655-1665

10. Haas M, Sis B, Racusen LC, Solez K, Glotz D, Colvin RB, Castro MC, David DS, David-Neto E, Bagnasco SM, Cendales LC, Cornell LD, Demetris AJ, Drachenberg CB, Farver CF, Farris AB 3rd, Gibson IW, Kraus E, Liapis H, Loupy A, Nickeleit V, Randhawa P, Rodriguez ER, Rush D, Smith RN, Tan CD, Wallace WD, Mengel M, Banff meeting report writing committee (2014) Banff 2013 meeting report: inclusion of c4d-negative antibodymediated rejection and antibody-associated arterial lesions. Am J Transplant 14:272-283

11. Mengel M, Sis B, Haas M, Colvin RB, Halloran PF, Racusen LC, Solez K, Cendales L, Demetris AJ, Drachenberg CB, Farver CF, Rodriguez ER, Wallace WD, Glotz D, Banff meeting report writing committee (2012) Banff 2011 meeting report: new concepts in antibody-mediated rejection. Am J Transplant 12:563-570

12. Solez K, Colvin RB, Racusen LC, Haas M, Sis B, Mengel M, Halloran PF, Baldwin W, Banfi G, Collins AB, Cosio F, David DS, Drachenberg C, Einecke G, Fogo AB, Gibson IW, Glotz D, Iskandar SS, Kraus E, Lerut E, Mannon RB, Mihatsch M, Nankivell BJ, Nickeleit V, Papadimitriou JC, Randhawa P, Regele H, Renaudin K, Roberts I, Seron D, Smith RN, Valente M (2008) Banff 07 classification of renal allograft pathology: updates and future directions. Am J Transplant 8:753-760

13. Solez K, Colvin RB, Racusen LC, Sis B, Halloran PF, Birk PE, Campbell PM, Cascalho M, Collins AB, Demetris AJ, Drachenberg CB, Gibson IW, Grimm PC, Haas M, Lerut E, Liapis H, Mannon RB, Marcus PB, Mengel M, Mihatsch MJ, Nankivell BJ, Nickeleit V, Papadimitriou JC, Platt JL, Randhawa P, Roberts I, Salinas-Madriga L, Salomon DR, Seron D, Sheaff M, Weening JJ (2007) Banff '05 Meeting Report: differential diagnosis of chronic allograft injury and elimination of chronic allograft nephropathy ('CAN'). Am J Transplant 7:518-526

14. Al-Lamki RS, Bradley JR, Pober JS (2008) Endothelial cells in allograft rejection. Transplantation 86:1340-1348

15. Pober JS, Jane-wit D, Qin L, Tellides G (2014) Interacting mechanisms in the pathogenesis of cardiac allograft vasculopathy. Arterioscler Thromb Vasc Biol 34:1609-1614
16. Rabelink TJ, Wijewickrama DC, de Koning EJ (2007) Peritubular endothelium: the Achilles heel of the kidney? Kidney Int 72:926930

17. Steegh FM, Gelens MA, Nieman FH, van Hooff JP, Cleutjens JP, van Suylen RJ, Daemen MJ, van Heurn EL, Christiaans MH, Peutz-Kootstra CJ (2011) Early loss of peritubular capillaries after kidney transplantation. J Am Soc Nephrol 22:1024-1029

18. Sis B, Jhangri GS, Bunnag S, Allanach K, Kaplan B, Halloran PF (2009) Endothelial gene expression in kidney transplants with alloantibody indicates antibody-mediated damage despite lack of C4d staining. Am J Transplant 9:2312-2323

19. Briscoe DM, Yeung AC, Schoen FJ, Allred EN, Stavrakis G, Ganz P, Cotran RS, Pober JS, Schoen EL (1995) Predictive value of inducible endothelial cell adhesion molecule expression for acute rejection of human cardiac allografts. Transplantation 59:204-211

20. Melter M, Exeni A, Reinders ME, Fang JC, McMahon G, Ganz P, Hancock WW, Briscoe DM (2001) Expression of the chemokine receptor CXCR3 and its ligand IP-10 during human cardiac allograft rejection. Circulation 104:2558-2564

21. Zhang X, Rozengurt E, Reed EF (2010) HLA class I molecules partner with integrin beta4 to stimulate endothelial cell proliferation and migration. Sci Signal 3:ra85

22. Bruneau S, Woda CB, Daly KP, Boneschansker L, Jain NG, Kochupurakkal N, Contreras AG, Seto T, Briscoe DM (2012) Key features of the intragraft microenvironment that determine long-term survival following transplantation. Front Immunol 3:54

23. Lee JR, Muthukumar T, Dadhania D, Ding R, Sharma VK, Schwartz JE, Suthanthiran M (2014) Urinary cell mRNA profiles predictive of human kidney allograft status. Immunol Rev 258: 218-240

24. Leibovich SJ, Polverini PJ, Shepard HM, Wiseman DM, Shively V, Nuseir N (1987) Macrophage-induced angiogenesis is mediated by tumour necrosis factor-alpha. Nature 329:630-632

25. Freeman MR, Schneck FX, Gagnon ML, Corless C, Soker S, Niknejad K, Peoples GE, Klagsbrun M (1995) Peripheral blood $\mathrm{T}$ lymphocytes and lymphocytes infiltrating human cancers express vascular endothelial growth factor: a potential role for T cells in angiogenesis. Cancer Res 55:4140-4145

26. Melter M, Reinders ME, Sho M, Pal S, Geehan C, Denton MD, Mukhopadhyay D, Briscoe DM (2000) Ligation of CD40 induces the expression of vascular endothelial growth factor by endothelial cells and monocytes and promotes angiogenesis in vivo. Blood 96:3801-3808

27. Reinders ME, Fang JC, Wong W, Ganz P, Briscoe DM (2003) Expression patterns of vascular endothelial growth factor in human cardiac allografts: association with rejection. Transplantation 76:224-230

28. Auerbach R, Sidky YA (1979) Nature of the stimulus leading to lymphocyte-induced angiogenesis. J Immunol 123:751-754

29. Cotran R (1994) Inflammation and repair. In: Cotran RS, Kumar V Jr, Robbins SL Jr (eds) Pathologic basis of disease. Saunders, Philadelphia, pp 51-92

30. Pober JS, Sessa WC (2007) Evolving functions of endothelial cells in inflammation. Nat Rev Immunol 7:803-815

31. Reinders ME, Rabelink TJ, Briscoe DM (2006) Angiogenesis and endothelial cell repair in renal disease and allograft rejection. J Am Soc Nephrol 17:932-942

32. Contreras AG, Briscoe DM (2007) Every allograft needs a silver lining. J Clin Invest 117:3645-3648

33. Babu AN, Murakawa T, Thurman JM, Miller EJ, Henson PM, Zamora MR, Voelkel NF, Nicolls MR (2007) Microvascular destruction identifies murine allografts that cannot be rescued from airway fibrosis. J Clin Invest 117:3774-3785

34. Moulton KS, Melder RJ, Dharnidharka VR, Hardin-Young J, Jain RK, Briscoe DM (1999) Angiogenesis in the huPBL-SCID model of human transplant rejection. Transplantation 67:1626-1631 
35. Fukumura D, Jain RK (2007) Tumor microvasculature and microenvironment: targets for anti-angiogenesis and normalization. Microvasc Res 74:72-84

36. Goel S, Duda DG, Xu L, Munn LL, Boucher Y, Fukumura D, Jain RK (2011) Normalization of the vasculature for treatment of cancer and other diseases. Physiol Rev 91:1071-1121

37. Jiang X, Khan MA, Tian W, Beilke J, Natarajan R, Kosek J, Yoder MC, Semenza GL, Nicolls MR (2011) Adenovirus-mediated HIF1alpha gene transfer promotes repair of mouse airway allograft microvasculature and attenuates chronic rejection. J Clin Invest 121:2336-2349

38. Miura M, El-Sawy T, Fairchild RL (2003) Neutrophils mediate parenchymal tissue necrosis and accelerate the rejection of complete major histocompatibility complex-disparate cardiac allografts in the absence of interferon-gamma. Am J Pathol 162: 509-519

39. Kupiec-Weglinski JW, Busuttil RW (2005) Ischemia and reperfusion injury in liver transplantation. Transplant Proc 37:1653-1656

40. El-Sawy T, Belperio JA, Strieter RM, Remick DG, Fairchild RL (2005) Inhibition of polymorphonuclear leukocyte-mediated graft damage synergizes with short-term costimulatory blockade to prevent cardiac allograft rejection. Circulation 112:320-331

41. Brinkmann V, Reichard U, Goosmann C, Fauler B, Uhlemann Y, Weiss DS, Weinrauch Y, Zychlinsky A (2004) Neutrophil extracellular traps kill bacteria. Science 303:1532-1535

42. Fuchs TA, Brill A, Duerschmied D, Schatzberg D, Monestier M, Myers DD Jr, Wrobleski SK, Wakefield TW, Hartwig JH, Wagner DD (2010) Extracellular DNA traps promote thrombosis. Proc Natl Acad Sci U S A 107:15880-15885

43. Kessenbrock K, Krumbholz M, Schönermarck U, Back W, Gross WL, Werb Z, Gröne HJ, Brinkmann V, Jenne DE (2009) Netting neutrophils in autoimmune small-vessel vasculitis. Nat Med 15: 623-625

44. Thomas GM, Carbo C, Curtis BR, Martinod K, Mazo IB, Schatzberg D, Cifuni SM, Fuchs TA, von Andrian UH, Hartwig JH, Aster RH, Wagner DD (2012) Extracellular DNA traps are associated with the pathogenesis of TRALI in humans and mice. Blood 119:6335-6343

45. Arai Y, Yamashita K, Mizugishi K, Watanabe T, Sakamoto S, Kitano T, Kondo T, Kawabata H, Kadowaki N, Takaori-Kondo A (2013) Serum neutrophil extracellular trap levels predict thrombotic microangiopathy after allogeneic stem cell transplantation. Biol Blood Marrow Transplant 19:1683-1689

46. Villanueva E, Yalavarthi S, Berthier CC, Hodgin JB, Khandpur R, Lin AM, Rubin CJ, Zhao W, Olsen SH, Klinker M, Shealy D, Denny MF, Plumas J, Chaperot L, Kretzler M, Bruce AT, Kaplan MJ (2011) Netting neutrophils induce endothelial damage, infiltrate tissues, and expose immunostimulatory molecules in systemic lupus erythematosus. J Immunol 187:538-552

47. Sayah DM, Mallavia B, Liu F, Ortiz-Muñoz G, Caudrillier A, DerHovanessian A, Ross DJ, Lynch Iii JP, Saggar R, Ardehali A, Ware LB, Christie JD, Belperio JA, Looney MR, Lung Transplant Outcomes Group Investigators (2015) Neutrophil extracellular traps are pathogenic in primary graft dysfunction after lung transplantation. Am J Respir Crit Care Med 191:455-463

48. Zeisberg EM, Tarnavski O, Zeisberg M, Dorfman AL, McMullen JR, Gustafsson E, Chandraker A, Yuan X, Pu WT, Roberts AB, Neilson EG, Sayegh MH, Izumo S, Kalluri R (2007) Endothelialto-mesenchymal transition contributes to cardiac fibrosis. Nat Med 13:952-961

49. Maleszewska M, Moonen JR, Huijkman N, van de Sluis B, Krenning G, Harmsen MC (2013) IL-1beta and TGFbeta2 synergistically induce endothelial to mesenchymal transition in an NFkappaB-dependent manner. Immunobiology 218:443-454

50. Sainson RC, Johnston DA, Chu HC, Holderfield MT, Nakatsu MN, Crampton SP, Davis J, Conn E, Hughes CC (2008) TNF primes endothelial cells for angiogenic sprouting by inducing a tip cell phenotype. Blood 111:4997-5007

51. Phung TL, Ziv K, Dabydeen D, Eyiah-Mensah G, Riveros M, Perruzzi C, Sun J, Monahan-Earley RA, Shiojima I, Nagy JA, Lin MI, Walsh K, Dvorak AM, Briscoe DM, Neeman M, Sessa WC, Dvorak HF, Benjamin LE (2006) Pathological angiogenesis is induced by sustained Akt signaling and inhibited by rapamycin. Cancer Cell 10:159-170

52. Dormond O, Contreras AG, Meijer E, Datta D, Flynn E, Pal S, Briscoe DM (2008) CD40-induced signaling in human endothelial cells results in mTORC2- and Akt-dependent expression of vascular endothelial growth factor in vitro and in vivo. J Immunol 181:8088-8095

53. Murao K, Ohyama T, Imachi H, Ishida T, Cao WM, Namihira H, Sato M, Wong NC, Takahara J (2000) TNF-alpha stimulation of MCP-1 expression is mediated by the Akt/PKB signal transduction pathway in vascular endothelial cells. Biochem Biophys Res Commun 276:791-796

54. Boulday G, Haskova Z, Reinders ME, Pal S, Briscoe DM (2006) Vascular endothelial growth factor-induced signaling pathways in endothelial cells that mediate overexpression of the chemokine IFN-gamma-inducible protein of $10 \mathrm{kDa}$ in vitro and in vivo. $\mathrm{J}$ Immunol 176:3098-3107

55. Wang C, Qin L, Manes TD, Kirkiles-Smith NC, Tellides G, Pober JS (2014) Rapamycin antagonizes TNF induction of VCAM-1 on endothelial cells by inhibiting mTORC2. J Exp Med 211:395-404

56. Dormond O, Dufour M, Seto T, Bruneau S, Briscoe DM (2012) Targeting the intragraft microenvironment and the development of chronic allograft rejection. Hum Immunol 73:1261-1268

57. Wedel J, Bruneau S, Kochupurakkal N, Boneschansker L, Briscoe DM (2015) Chronic allograft rejection: a fresh look. Curr Opin Org Transplant 20:13-20

58. Bruneau S, Nakayama H, Woda CB, Flynn EA, Briscoe DM (2013) DEPTOR regulates vascular endothelial cell activation and proinflammatory and angiogenic responses. Blood 122: $1833-1842$

59. Jindra PT, Jin YP, Jacamo R, Rozengurt E, Reed EF (2008) MHC class I and integrin ligation induce ERK activation via an mTORC2-dependent pathway. Biochem Biophys Res Commun 369:781-787

60. Jindra PT, Jin YP, Rozengurt E, Reed EF (2008) HLA class I antibody-mediated endothelial cell proliferation via the mTOR pathway. J Immunol 180:2357-2366

61. Wang C, Yi T, Qin L, Maldonado RA, von Andrian UH, Kulkarni S, Tellides G, Pober JS (2013) Rapamycin-treated human endothelial cells preferentially activate allogeneic regulatory $\mathrm{T}$ cells. $\mathrm{J}$ Clin Invest 123:1677-1693

62. Laplante M, Sabatini DM (2009) mTOR signaling at a glance. J Cell Sci 122:3589-3594

63. Kang SA, Pacold ME, Cervantes CL, Lim D, Lou HJ, Ottina K, Gray NS, Turk BE, Yaffe MB, Sabatini DM (2013) mTORC1 phosphorylation sites encode their sensitivity to starvation and rapamycin. Science 341:1236566

64. Kim DH, Sarbassov DD, Ali SM, King JE, Latek RR, ErdjumentBromage H, Tempst P, Sabatini DM (2002) mTOR interacts with raptor to form a nutrient-sensitive complex that signals to the cell growth machinery. Cell 110:163-175

65. Kim DH, Sarbassov DD, Ali SM, Latek RR, Guntur KV, Erdjument-Bromage H, Tempst P, Sabatini DM (2003) GbetaL, a positive regulator of the rapamycin-sensitive pathway required for the nutrient-sensitive interaction between raptor and mTOR. Mol Cell 11:895-904

66. Sancak Y, Thoreen CC, Peterson TR, Lindquist RA, Kang SA, Spooner E, Carr SA, Sabatini DM (2007) PRAS40 is an insulinregulated inhibitor of the mTORC1 protein kinase. Mol Cell 25: 903-915 
67. Peterson TR, Laplante M, Thoreen CC, Sancak Y, Kang SA, Kuehl WM, Gray NS, Sabatini DM (2009) DEPTOR is an mTOR inhibitor frequently overexpressed in multiple myeloma cells and required for their survival. Cell 137:873-886

68. Zinzalla V, Stracka D, Oppliger W, Hall MN (2011) Activation of mTORC2 by association with the ribosome. Cell 144:757-768

69. Guertin DA, Stevens DM, Thoreen CC, Burds AA, Kalaany NY, Moffat J, Brown M, Fitzgerald KJ, Sabatini DM (2006) Ablation in mice of the mTORC components raptor, rictor, or mLST8 reveals that $\mathrm{mTORC} 2$ is required for signaling to Akt-FOXO and PKCalpha, but not S6K1. Dev Cell 11:859-871

70. Sarbassov DD, Ali SM, Kim DH, Guertin DA, Latek RR, Erdjument-Bromage H, Tempst P, Sabatini DM (2004) Rictor, a novel binding partner of mTOR, defines a rapamycin-insensitive and raptor-independent pathway that regulates the cytoskeleton. Curr Biol 14:1296-1302

71. Jacinto E, Loewith R, Schmidt A, Lin S, Rüegg MA, Hall A, Hall MN (2004) Mammalian TOR complex 2 controls the actin cytoskeleton and is rapamycin insensitive. Nat Cell Biol 6:1122-1128

72. Frias MA, Thoreen CC, Jaffe JD, Schroder W, Sculley T, Carr SA, Sabatini DM (2006) mSin 1 is necessary for Akt/PKB phosphorylation, and its isoforms define three distinct mTORC2s. Curr Biol 16:1865-1870

73. Pearce LR, Huang X, Boudeau J, Pawłowski R, Wullschleger S, Deak M, Ibrahim AF, Gourlay R, Magnuson MA, Alessi DR (2007) Identification of Protor as a novel Rictor-binding component of mTOR complex-2. Biochem J 405:513-522

74. Dibble CC, Asara JM, Manning BD (2009) Characterization of Rictor phosphorylation sites reveals direct regulation of mTOR complex 2 by S6K1. Mol Cell Biol 29:5657-5670

75. Procaccini C, De Rosa V, Galgani M, Abanni L, Calì G, Porcellini A, Carbone F, Fontana S, Horvath TL, La Cava A, Matarese G (2010) An oscillatory switch in mTOR kinase activity sets regulatory T cell responsiveness. Immunity 33:929-941

76. Gao D, Inuzuka H, Tan MK, Fukushima H, Locasale JW, Liu P, Wan L, Zhai B, Chin YR, Shaik S, Lyssiotis CA, Gygi SP, Toker A, Cantley LC, Asara JM, Harper JW, Wei W (2011) mTOR drives its own activation via $\mathrm{SCF}$ (betaTrCP)-dependent degradation of the mTOR inhibitor DEPTOR. Mol Cell 44:290-303

77. Zhao Y, Xiong X, Sun Y (2011) DEPTOR, an mTOR inhibitor, is a physiological substrate of $\mathrm{SCF}$ (betaTrCP) E3 ubiquitin ligase and regulates survival and autophagy. Mol Cell 44:304-316

78. Luo Z, Pan Y, Jeong LS, Liu J, Jia L (2012) Inactivation of the Cullin (CUL)-RING E3 ligase by the NEDD8-activating enzyme inhibitor MLN4924 triggers protective autophagy in cancer cells. Autophagy 8:1677-1679

79. Liu M, Wilk SA, Wang A, Zhou L, Wang RH, Ogawa W, Deng C, Dong LQ, Liu F (2010) Resveratrol inhibits mTOR signaling by promoting the interaction between mTOR and DEPTOR. J Biol Chem 285:36387-36394

80. Das F, Bera A, Ghosh-Choudhury N, Abboud HE, Kasinath BS, Choudhury GG (2014) TGFbeta-induced deptor suppression recruits mTORC1 and not mTORC2 to enhance collagen I (alpha2) gene expression. PLoS One 9:e109608

81. Bijkerk R, van Solingen C, de Boer HC, van der Pol P, Khairoun $M$, de Bruin RG, van Oeveren-Rietdijk AM, Lievers E, Schlagwein N, van Gijlswijk DJ, Roeten MK, Neshati Z, de Vries AA, Rodijk M, Pike-Overzet K, van den Berg YW, van der Veer EP, Versteeg HH, Reinders ME, Staal FJ, van Kooten C, Rabelink TJ, van Zonneveld AJ (2014) Hematopoietic microRNA-126 protects against renal ischemia/reperfusion injury by promoting vascular integrity. J Am Soc Nephrol 25:1710-1722

82. Anglicheau D, Sharma VK, Ding R, Hummel A, Snopkowski C, Dadhania D, Seshan SV, Suthanthiran M (2009) MicroRNA expression profiles predictive of human renal allograft status. Proc Natl Acad Sci U S A 106:5330-5335
83. Mitchell PS, Parkin RK, Kroh EM, Fritz BR, Wyman SK, Pogosova-Agadjanyan EL, Peterson A, Noteboom J, O'Briant KC, Allen A, Lin DW, Urban N, Drescher CW, Knudsen BS, Stirewalt DL, Gentleman R, Vessella RL, Nelson PS, Martin DB, Tewari M (2008) Circulating microRNAs as stable bloodbased markers for cancer detection. Proc Natl Acad Sci U S A 105:10513-10518

84. Weber JA, Baxter DH, Zhang S, Huang DY, Huang KH, Lee MJ, Galas DJ, Wang K (2010) The microRNA spectrum in 12 body fluids. Clin Chem 56:1733-1741

85. Mas VR, Dumur CI, Scian MJ, Gehrau RC, Maluf DG (2013) MicroRNAs as biomarkers in solid organ transplantation. Am J Transplant 13:11-19

86. Hartono C, Muthukumar T, Suthanthiran M (2010) Noninvasive diagnosis of acute rejection of renal allografts. Curr Opin Org Transplant 15:35-41

87. Rabelink TJ, de Boer HC, van Zonneveld AJ (2010) Endothelial activation and circulating markers of endothelial activation in kidney disease. Nat Rev Nephrol 6:404-414

88. Fish JE, Santoro MM, Morton SU, Yu S, Yeh RF, Wythe JD, Ivey KN, Bruneau BG, Stainier DY, Srivastava D (2008) miR-126 regulates angiogenic signaling and vascular integrity. Dev Cell $15: 272-284$

89. Wang S, Aurora AB, Johnson BA, Qi X, McAnally J, Hill JA, Richardson JA, Bassel-Duby R, Olson EN (2008) The endothelial-specific microRNA miR-126 governs vascular integrity and angiogenesis. Dev Cell 15:261-271

90. Kuhnert F, Mancuso MR, Hampton J, Stankunas K, Asano T, Chen CZ, Kuo CJ (2008) Attribution of vascular phenotypes of the murine Egfl7 locus to the microRNA miR-126. Development 135:3989-3993

91. Van Solingen C, Seghers L, Bijkerk R, Duijs JM, Roeten MK, van Oeveren-Rietdijk AM, Baelde HJ, Monge M, Vos JB, de Boer HC, Quax PH, Rabelink TJ, van Zonneveld AJ (2009) Antagomir-mediated silencing of endothelial cell specific microRNA-126 impairs ischemia-induced angiogenesis. J Cell Mol Med 13:1577-1585

92. Harris TA, Yamakuchi M, Ferlito M, Mendell JT, Lowenstein CJ (2008) MicroRNA-126 regulates endothelial expression of vascular cell adhesion molecule 1. Proc Natl Acad Sci U S A 105:15161521

93. Asgeirsdottir SA, van Solingen C, Kurniati NF, Zwiers PJ, Heeringa P, van Meurs M, Satchell SC, Saleem MA, Mathieson PW, Banas B, Kamps JA, Rabelink TJ, van Zonneveld AJ, Molema G (2012) MicroRNA-126 contributes to renal microvascular heterogeneity of VCAM-1 protein expression in acute inflammation. Am J Physiol Renal Physiol 302:F1630-F1639

94. Grundmann S, Hans FP, Kinniry S, Heinke J, Helbing T, Bluhm F, Sluijter JP, Hoefer I, Pasterkamp G, Bode C, Moser M (2011) MicroRNA-100 regulates neovascularization by suppression of mammalian target of rapamycin in endothelial and vascular smooth muscle cells. Circulation 123:999-1009

95. Jin C, Zhao Y, Yu L, Xu S, Fu G (2013) MicroRNA-21 mediates the rapamycin-induced suppression of endothelial proliferation and migration. FEBS Lett 587:378-385

96. Kumarswamy R, Volkmann I, Jazbutyte V, Dangwal S, Park DH, Thum $T$ (2012) Transforming growth factor-beta-induced endothelial-to-mesenchymal transition is partly mediated by microRNA-21. Arterioscler Thromb Vasc Biol 32:361-369

97. Zhang XY, Shen BR, Zhang YC, Wan XJ, Yao QP, Wu GL, Wang JY, Chen SG, Yan ZQ, Jiang ZL (2013) Induction of thoracic aortic remodeling by endothelial-specific deletion of microRNA21 in mice. PLoS One 8:e59002

98. Suarez Y, Wang C, Manes TD, Pober JS (2010) Cutting edge: TNF-induced microRNAs regulate TNF-induced expression of E-selectin and intercellular adhesion molecule-1 on human 
endothelial cells: feedback control of inflammation. J Immunol $184: 21-25$

99. Sun X, Icli B, Wara AK, Belkin N, He S, Kobzik L, Hunninghake GM, Vera MP, Registry MICU, Blackwell TS, Baron RM, Feinberg MW (2012) MicroRNA-181b regulates NF-kappaBmediated vascular inflammation. J Clin Invest 122:1973-1990

100. Fang Y, Shi C, Manduchi E, Civelek M, Davies PF (2010) MicroRNA-10a regulation of proinflammatory phenotype in athero-susceptible endothelium in vivo and in vitro. Proc Natl Acad Sci U S A 107:13450-13455

101. Zhu N, Zhang D, Chen S, Liu X, Lin L, Huang X, Guo Z, Liu J, Wang Y, Yuan W, Qin Y (2011) Endothelial enriched microRNAs regulate angiotensin II-induced endothelial inflammation and migration. Atherosclerosis 215:286-293

102. Cheng HS, Sivachandran N, Lau A, Boudreau E, Zhao JL, Baltimore D, Delgado-Olguin P, Cybulsky MI, Fish JE (2013) MicroRNA-146 represses endothelial activation by inhibiting pro-inflammatory pathways. EMBO Mol Med 5:949-966

103. Valadi H, Ekström K, Bossios A, Sjöstrand M, Lee JJ, Lötvall JO (2007) Exosome-mediated transfer of mRNAs and microRNAs is a novel mechanism of genetic exchange between cells. Nat Cell Biol 9:654-659

104. Hunter MP, Ismail N, Zhang X, Aguda BD, Lee EJ, Yu L, Xiao T, Schafer J, Lee ML, Schmittgen TD, Nana-Sinkam SP, Jarjoura D, Marsh CB (2008) Detection of microRNA expression in human peripheral blood microvesicles. PLoS One 3:e3694

105. Gilad S, Meiri E, Yogev Y, Benjamin S, Lebanony D, Yerushalmi N, Benjamin H, Kushnir M, Cholakh H, Melamed N, Bentwich Z, Hod M, Goren Y, Chajut A (2008) Serum microRNAs are promising novel biomarkers. PLoS One 3:e3148

106. Li L, Khush K, Hsieh SC, Ying L, Luikart H, Sigdel T, Roedder S, Yang A, Valantine H, Sarwal MM (2013) Identification of common gene signatures for the diagnosis of renal and cardiac acute allograft rejection. PLoS One 16:e82153

107. Halloran PF, Pereira AB, Chang J, Matas A, Picton M, De Freitas D, Bromberg J, Serón D, Sellarés J, Einecke G, Reeve J (2013) Microarray diagnosis of antibody-mediated rejection in kidney transplant biopsies: an international prospective study (INTERCOM). Am J Transplant 13:2865-2874

108. Daly KP, Stack MP, Eisenga M, Keane J, Zurakowski D, Blume E, Briscoe D (2014) VEGF-A predicts the development of moderate or severe cardiac allograft vasculopathy in pediatric heart transplant recipients. Am J Transplant 14 [Suppl 3]:4

109. Daly K, Starling R, Armstrong B, Ikle D, Bridges N, Chandraker A, Sayegh M, Stehlik J, Heeger P, Briscoe D (2014) Changes in plasma levels of VEGF-C and Endothelin-1 during the first posttransplant year are predictive of cardiac allograft vasculopathy: results from the CTOT-05 study. Am J Transplant Suppl 14:878

110. Danger R, Pallier A, Giral M, Martínez-Llordella M, Lozano JJ, Degauque N, Sanchez Fueyo A, Soulillou JP, Brouard S (2012) Upregulation of miR-142-3p in peripheral blood mononuclear cells of operationally tolerant patients with a renal transplant. J Am Soc Nephrol 23:597-606

111. Danger R, Paul C, Giral M, Lavault A, Foucher Y, Degauque N, Pallier A, Durand M, Castagnet S, Duong Van Huyen JP, Delahousse M, Renaudin K, Soulillou JP, Brouard S (2013) Expression of miR-142-5p in peripheral blood mononuclear cells from renal transplant patients with chronic antibody-mediated rejection. PLoS One 8:e60702
112. Wei L, Wang M, Qu X, Mah A, Xiong X, Harris AGC, Phillips LK, Martinez OM, Krams SM (2012) Differential expression of microRNAs during allograft rejection. Am J Transplant 12:11131123

113. Lorenzen JM, Volkmann I, Fiedler J, Schmidt M, Scheffner I, Haller H, Gwinner W, Thum T (2011) Urinary miR-210 as a mediator of acute T-cell mediated rejection in renal allograft recipients. Am J Transplant 11:2221-2227

114. Scian MJ, Maluf DG, David KG, Archer KJ, Suh JL, Wolen AR, Mba MU, Massey HD, King AL, Gehr T, Cotterell A, Posner M, Mas V (2011) MicroRNA profiles in allograft tissues and paired urines associate with chronic allograft dysfunction with IF/TA. Am J Transplant 11:2110-2122

115. Maluf DG, Dumur CI, Suh JL, Scian MJ, King AL, Cathro H, Lee JK, Gehrau RC, Brayman KL, Gallon L, Mas VR (2014) The urine microRNA profile may help monitor post-transplant renal graft function. Kidney Int 85:439-449

116. Wu XY, Fan WD, Fang R, Wu GF (2014) Regulation of microRNA-155 in endothelial inflammation by targeting nuclear factor (NF)-kappaB P65. J Cell Biochem 115:19281936

117. Sun HX, Zeng DY, Li RT, Pang RP, Yang H, Hu YL, Zhang Q, Jiang Y, Huang LY, Tang YB, Yan GJ, Zhou JG (2012) Essential role of microRNA-155 in regulating endothelium-dependent vasorelaxation by targeting endothelial nitric oxide synthase. Hypertension 60:1407-1414

118. Dai GH, Ma PZ, Song XB, Liu N, Zhang T, Wu B (2014) MicroRNA-223-3p inhibits the angiogenesis of ischemic cardiac microvascular endothelial cells via affecting RPS6KB1/hif-1a signal pathway. PLoS One 9:e108468

119. Shi L, Fisslthaler B, Zippel N, Fromel T, Hu J, Elgheznawy A, Heide H, Popp R, Fleming I (2013) MicroRNA-223 antagonizes angiogenesis by targeting betal integrin and preventing growth factor signaling in endothelial cells. Circ Res 113: $1320-1330$

120. Huang Y, Liu Y, Li L, Su B, Yang L, Fan W, Yin Q, Chen L, Cui T, Zhang J, Lu Y, Cheng J, Fu P, Liu F (2014) Involvement of inflammation-related miR-155 and miR-146a in diabetic nephropathy: implications for glomerular endothelial injury. BMC Nephrol 15:142

121. Wei Y, Nazari-Jahantigh M, Neth P, Weber C, Schober A (2013) MicroRNA-126, -145, and -155: a therapeutic triad in atherosclerosis? Arterioscler Thromb Vasc Biol 33:449-454

122. Bijkerk R, de Bruin RG, van Solingen C, Duijs JM, Kobayashi K, van der Veer EP, ten Dijke P, Rabelink TJ, Goumans MJ, van Zonneveld AJ (2012) MicroRNA-155 functions as a negative regulator of RhoA signaling in TGF-beta-induced endothelial to mesenchymal transition. Microrna 1:2-10

\section{1. d \\ 2. e \\ 3. $\mathrm{b}$ \\ 4. $b$ \\ 5. d}

Answers 